\title{
Compensatory Growth of the Juvenile Brown Floun- der Paralichthysolivaceus Following Being Kept at High Temperature for a Single Phase of Different Length
}

\author{
Liu Xujia ${ }^{1,3}$, Peng Yinhui ${ }^{1}$, Huang Guoqiang ${ }^{1,2,3^{*}}$, Wei Liuzhi ${ }^{3}$, Zhang Xiumei ${ }^{3}$ \\ ${ }^{1}$ Guangxi Key Laboratoryof Marine Biotechnology, Guangxi Institute of Oceanology, Beihai 536000, China \\ ${ }^{2}$ Ocean college, Qinzhou University, Qinzhou 535011, China \\ ${ }^{3}$ Key Laboratory of Mariculture, Ministry of Education, Ocean University of China, Qingdao 266003, China
}

*Corresponding author: Huang Guoqiang,Guangxi Key Laboratoryof Marine Biotechnology, Guangxi Institute of Oceanology, Beihai 536000, China, E-mail: hugh7531@163.com

\begin{abstract}
:
The compensatory growth of juvenile brown flounder (Paralichthysolivaceus) with an average initial weight of $0.8 \mathrm{~g}$ exposed to high temperature for a single phase of different length was determined. Nine hundred juvenile flounders were randomly distributed in 15 re-circulating glass aquaria. The fish were exposed to high temperature $26^{\circ} \mathrm{C}$ for 0 (control group), 10, 20, 30 and 40 days, followed by optimal temperature $20^{\circ} \mathrm{C}$ for $70,60,50$ and 40 days, respectively. The weights of fish exposed for 10 and 20 days to $26^{\circ} \mathrm{C}$ were recovered to the levels of control fish, while those of the other two treatments for 30 and 40 days to $26^{\circ} \mathrm{C}$ were still significantly lower than the control. During the high temperature stress for different length, weight, specific growth rate (SGR) and feed conversion efficiency (FCE) of fish were significantly lower, while the feeding rate (FR) were higher $(P<0.05)$ than those of fish in the control treatment $(P<0.05)$. There were no significant differences in feeding rate between the high temperature for 10 and 20 days and control treatment during the recovery period. The feed conversion of high temperature exposed fish improved in recovery periods but not exceed the control treatment. Analysis of the data indicated that the compensatory growth in the recovery period depended on greatly improved feed conversion efficiency and slightly higher feeding rate. Results of this study support a reference function and have practical significance for juvenile P.olivaceus culture and enhancement.
\end{abstract}

Keywords: Brown flounder; Compensatory growth; High temperature exposure; Feeding rate; Feed conversion efficiency

\section{Introduction}

Temperature is a dominant abiotic factor controlling feeding and growth, it is of high interest to study the effects of this critical ecological factor on fish growth performances. Reports revealed that temperature could be manipulated to achieve compensatory growth in several species of teleosts. Following being kept at low temperature for a period, compensatory growth appeared in Atlantic salmon (Salmo salar) ${ }^{[1,2]}$, Arctic charr (Salvelinusalpinus) ${ }^{[1]}$, Mossambicatilapia (Oreochromis mossambicus) ${ }^{[3]}$, Atlantic cod (Gadusmorhua $)^{[4]}$, Schlegel's black rockfish (Sebastes schlegeli) ${ }^{[5]}$, brown flounder (Paralichthysolivaceus) ${ }^{[6,7]}$, tongue sole (Cynoglossussemilaevis) ${ }^{[8]}$, etc after switch to normal warm water. These researches revealed the growth flexibility and adaptive faculty of teleosts species to water environment with large-scale temperature fluctuation.However, compensatory growth achieved by high temperature manipulating is still scarcely reported, except for ${ }^{[6]}$ reported the complete compensatory growth of juvenile brown flounder following 10 days 26.5 ${ }^{\circ} \mathrm{C}$ exposure and ${ }^{[9]}$ reported complete compensatory growth of juvenile tongue sole (Cynoglossussemilaevis) following being reared at $28^{\circ} \mathrm{C}$ for 2 and 3 weeks. Lack of information may cre- ate a false illusion that high temperature adaptability of teleosts is inferior to low temperature adaptability. It also obstructs the better development of the culture of some economical important fish. The brown flounder (Paralichthysolivaceus), is one of the most important species for mariculture and enhancement in the coastal areas of northern China ${ }^{[10]}$. The optimal temperature range for brown flounder $\left(20-25^{\circ} \mathrm{C}\right.$ at $\left.4-176 \mathrm{~g}\right)$ decreases in proportion to body mass $\left(\text { c. } 15^{\circ} \mathrm{C} \text { when fish mass is }>700 \mathrm{~g}\right)^{[11]}$. So, culture of brown flounder rarely encountered the challenge of high temperature in northern china. In recent years, brown

\section{Received date: September 09, 2017 \\ Accepted Date: March 15, 2018 \\ Published Date: March 20, 2018}

Citation: Guoqiang, H. Compensatory Growth of the Juvenile Brown Flounder Paralichthysolivaceus Following Being Kept at High Temperature for a Single Phase of Different Length. (2018) J Marine Biol Aquacult 4(1): 21- 26.

Copy Rights: (C) 2018 Guoqiang, H. This is an Open access article distributed under the terms of Creative Commons Attribution 4.0 International License. 
flounder was also cultured in outdoor ponds, indoor tanks, and net cages in southern coastal regions. In this case, they may be exposed to a long term high temperature in summer. So potential mechanism to adaptive the pressure of high temperature is crucial for this species, or it would be disadvantageous in an environment which high temperature last for a long period ${ }^{[6]}$. Observed completely compensatory growth of brown flounder following a short period of warm water exposure and concluded that short periods of high-temperature stress may not delay the annual growth of brown flounder. But high temperature could last for several months in coastal areas of southern china. The capacity of high temperature induced compensatory growth would be important to selection of site, time, and size of fry for brown flounder culture. So, the present study was based on previous research and extended to investigate whether the juvenile brown flounder could compensate the growth delay caused by longer period of high temperature exposure.

\section{Material and Methods}

\section{Source and acclimation of fish}

The juvenile $P$. olivaceus used in the present experiment were collected from a commercial fish hatchery in Wendeng, Shandong Province, P.R. China. The study used experimental ecology methods and was conducted from April 20 2011 to June $4^{\text {th }}, 2012$ in the laboratory of Ocean University of China. The juvenile fish purchased were about 70 days old and weighed about $0.5 \mathrm{~g}$. Prior to the experiment, the fish were transferred to aquaria $\left(150 \times 200 \times 100 \mathrm{~cm}\right.$, about $\left.3 \mathrm{~m}^{3}\right)$ with recirculating water at controlled temperature and experienced a 15-day acclimation period, during which the water temperature was about 20 ${ }^{\circ} \mathrm{C}$ and the fish were fed commercial formulated feed to satiation level twice a day (at about 07:00 and 18:00). The composition of the feed was: moisture $13.9 \mathrm{~g} / \mathrm{kg}$, protein $486.8 \mathrm{~g} / \mathrm{kg}$, lipid 227.0 $\mathrm{g} / \mathrm{kg}$, carbohydrate $182.9 \mathrm{~g} / \mathrm{kg}$, ash $62.5 \mathrm{~g} / \mathrm{kg}$, and energy 23.65 $\mathrm{MJ} / \mathrm{kg}$.

\section{Experimental design}

Following acclimation, the fish experienced $24 \mathrm{~h}$ food deprivation, then 900 healthy fish with an initial mean weight of about $0.8 \mathrm{~g}$ were selected and randomly assigned to 15 aquaria for five treatments. The fish were exposed to 5 different treatments: the fish of controlwere continuously reared at optimal temperature $20^{\circ} \mathrm{C}$ and the fish of other four treatments were reared at high temperature $26^{\circ} \mathrm{C}$ for 10 days $(\mathrm{H} 10)$ and recovery $20^{\circ} \mathrm{C}$ for 70 days, high temperature $26^{\circ} \mathrm{C}$ for 20 days and recovery $20^{\circ} \mathrm{C}$ for 60 days (H20), high temperature $26^{\circ} \mathrm{C}$ for 30 days and recovery $20^{\circ} \mathrm{C}$ for 50 days $(\mathrm{H} 30)$, and high temperature 26 ${ }^{\circ} \mathrm{C}$ for 40 days and recovery $20^{\circ} \mathrm{C}$ for 40 days (H40) respectively. When high-temperature exposure finished, the temperature was gradually adjusted to $20^{\circ} \mathrm{C}$ within 3 days to observe the compensatory growth. Three aquaria were assigned to each treatment and each aquarium was stocked with 60 fish.

\section{Rearing conditions}

Juvenile P. olivaceus were held in glass aquaria $(800 \times$ $500 \times 350 \mathrm{~mm}$, water volume $140 \mathrm{~L}$ ) with re-circulating water at controlled temperature (electronic-controlledheating rods and chillerwas adopted to keep the water temperature). Aeration was provided continuously and the water flow rate for each rearing unit was around $3.0 \mathrm{~L} / \mathrm{min}$. During the course of the experiment, dissolved oxygen was maintained at $>5.5 \mathrm{mg} / \mathrm{L}, \mathrm{pH}$ about 7.8 , salinity between 30 and 33. A simulated natural photoperiod (14L: 10D) was used.

\section{Sample collection and analysis}

During the experiment, fish were starved for $24 \mathrm{~h}$ every tenth day and then weighed. Daily feed supplied was weighed and recorded. Uneaten feed was collected after feeding $1 \mathrm{~h}$ and then dried to constant mass in an oven at $70^{\circ} \mathrm{C}$. An experiment was designed to measure the feed mass loss caused by immersion in sea water over $1 \mathrm{~h}$.

\section{Calculation of data}

Specific growth rate (SGR), feeding rate (FR), and FCE were calculated each ten days, and during the whole experimental period, high-temperature exposure period, and recovery period, respectively. SGR (\% weight/d), FR (\% weight/d) and FCE (\%) were calculated as follows:

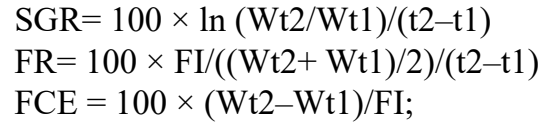

Where $\mathrm{t} 2$ and $\mathrm{t} 1$ were the final and initial time in the experiment, and $\mathrm{Wt} 2$ and $\mathrm{Wt} 1$ werethe weight at the final and initial time, respectively. FI was feed ingestion during the period of the experiment.

\section{Statistical analysis}

Statistics were performed using SPSS statistical software (SPSS 11.5 for Windows; SPSS, Chicago, IL, U.S.A.). The comparisons among the body weight of fish in different treatments were tested by one-way ANOVA and Duncan's multiple range tests were used to test the differences of each variable between treatments. The data of specific growth rate (SGR), feeding rate (FR), and feed conversion efficiency (FCE) were analyzed by ANCOVA. Differences were considered significant at a probability level of 0.05 .

\section{Results}

\section{Weight and specific growthrate}

Following different lengths of high-temperature exposure, the body weights of fish were significantly smaller than the control (Figure 1). After being transferred to $20^{\circ} \mathrm{C}$, the weight of fish exposed to 10 days high temperature caught up to the control weight in 10 days and the weight of fish exposed for 20 days caught up to the control weight in 40 days (no significant difference was observed at the twentieth and thirtieth day after temperature adjusting, but they were still smaller than the control) (Figure 1). Weight of fish exposed to $26^{\circ} \mathrm{C}$ for 30 days and 40 days were still significantly lower than the control at the end of the experiment (Figure 1). 


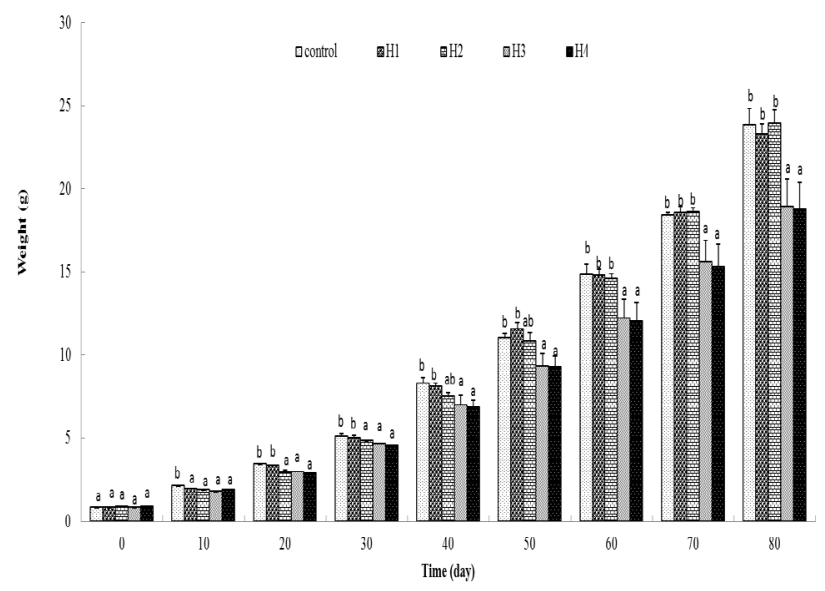

Figure 1: Body fresh weight (g) of the juvenile P.olivaceus. Column without same letter in the same cluster were significantly different from each other $(\mathrm{P}<0.05)$.

It was found that the SGRs of high-temperature exposed fish were significantly lower than in days 1-10 and were not significantly different from the control in any of the following periods (Figure 2). Compared to the control, significantly higherSGR only appeared in fish exposed for 10 days high temperature for 11-20 days (the first ten days of recovery) and no difference between high-temperature exposure and the control was observed in recovery periods (Figure 2). SGR of the whole experimental period after 30 and 40 days high-temperature exposure were significantly lower than the control (Figure 2). During $26{ }^{\circ} \mathrm{C}$ exposed periods, the average SGR of all fish were significantly lower than the control (Table 1). For the recovery period, average SGR of 10and 20-day exposed fish were slightly higher than the control, whereas the average SGR of 30 and 40day exposed fish were slightly lower than the control (Table 2). Average SGRs in all recovery treatments were not significantly different to the control (Table 2).

Table 1: Specific growth rate (\%weight/day) of juvenile P. olivaceus during exposure to high temperature

\begin{tabular}{|c|c|c|c|c|}
\hline $\begin{array}{l}\text { P e r i o d s } \\
\text { (days) }\end{array}$ & 10 days & 20 days & 30 days & 40 days \\
\hline $\begin{array}{l}\text { High-tem- } \\
\text { perature ex- } \\
\text { posure }\end{array}$ & $\begin{array}{ll}8.52 & \pm \\
0.17 * & \end{array}$ & $\begin{array}{l}6.38 \\
0.02 *\end{array}$ & $\begin{array}{l}5.96 \\
0.02 *\end{array}$ & $\begin{array}{ll}5.26 & \pm \\
0.02 * & \end{array}$ \\
\hline control & $9.46 \pm 0.07$ & $7.25 \pm 0.11$ & $6.22 \pm 0.04$ & $5.85 \pm 0.11$ \\
\hline
\end{tabular}

* indicates significant difference between high-temperature exposure and control.

Table 2: Specific growth rate (\%weight/day) of juvenile $P$. olivaceus during recovery periods

\begin{tabular}{|l|l|l|l|l|}
\hline $\begin{array}{l}\text { P e r i o d s } \\
\text { (days) }\end{array}$ & 70 days & 60 days & 50 days & 40 days \\
\hline recovery & $3.63 \pm 0.05$ & $3.48 \pm 0.09$ & $2.83 \pm 0.15$ & $2.49 \pm 0.11$ \\
\hline control & $3.51 \pm 0.07$ & $3.27 \pm 0.01$ & $3.10 \pm 0.09$ & $2.67 \pm 0.01$ \\
\hline
\end{tabular}

* indicates a significant difference between recovery and control $(\mathrm{P}<0.05)$.

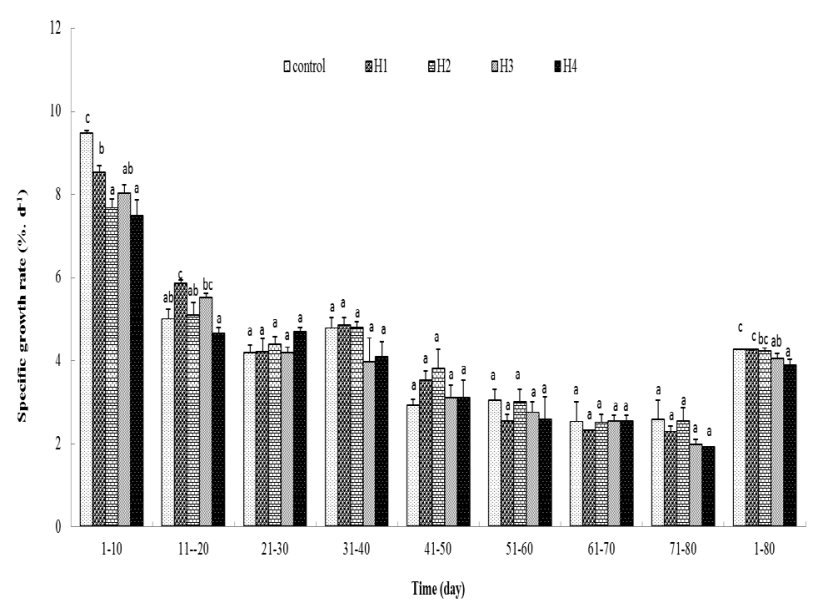

Figure 2: Specific growth rate (\%.d-1) of the juvenile P.olivaceus. Column without same letter in the same cluster were significantly different from each other $(\mathrm{P}<0.05)$.

\section{Feeding rate}

Through the first 20 days of exposure to high temperature (only 10 days for 10-day exposed fish), the FRsof fish were significantly higher than the control and FR of 40-day exposed fish were higher than the control at 31-40 days (Figure 3). In different periods of recovery, only the FR of 20 and 30-day exposed fish during 41-50 and 71-80 days respectively, were higher than the control (Figure 3). It was found that throughout the whole experiment period, FR after 30 and 40 days high-temperature exposure were obviously higher than the control, and FR after 10 and 20 days exposure were slightly higher than the control (Figure 3). For the whole period of exposure to high temperature, FR of 20, 30, and 40-day exposed fish were obviously higher than the control and FR of 10-day exposed fish was slightly higher than the control (Table 3). For the whole recovery period, FR of high-temperature exposed fish was slightly higher than the control (Table 4).

Table 3: Feeding rate (\%weight/day) of juvenile $P$. olivaceus during exposure to high temperature

\begin{tabular}{|l|l|l|l|l|}
\hline $\begin{array}{l}\text { P e r i o d s } \\
\text { (days) }\end{array}$ & 10 days & 20 days & 30 days & 40 days \\
\hline $\begin{array}{l}\text { High-tem- } \\
\text { perature ex- } \\
\text { posure }\end{array}$ & $5.36 \pm 0.17$ & $5.15 \pm 0.26^{*}$ & $4.09 \pm 0.19^{*}$ & $\begin{array}{l}3.26 \pm 0.11 \\
*\end{array}$ \\
\hline control & $4.66 \pm 0.12$ & $3.92 \pm 0.09$ & $3.21 \pm 0.03$ & $2.48 \pm 0.01$ \\
\hline
\end{tabular}

* indicates a significant difference between high-temperature exposure and control.

Table 4: Feeding rate (\%weight/day) of juvenile P. olivaceus during recovery periods

\begin{tabular}{|l|l|l|l|l|}
\hline $\begin{array}{l}\text { P e r i o d s } \\
\text { (days) }\end{array}$ & 70 days & 60 days & 50 days & 40 days \\
\hline recovery & $1.59 \pm 0.06$ & $1.71 \pm 0.05$ & $1.75 \pm 0.11$ & $1.62 \pm 0.09$ \\
\hline control & $1.53 \pm 0.04$ & $1.59 \pm 0.04$ & $1.62 \pm 0.06$ & $1.59 \pm 0.05$ \\
\hline
\end{tabular}

* indicates a significant difference between recovery and control. 


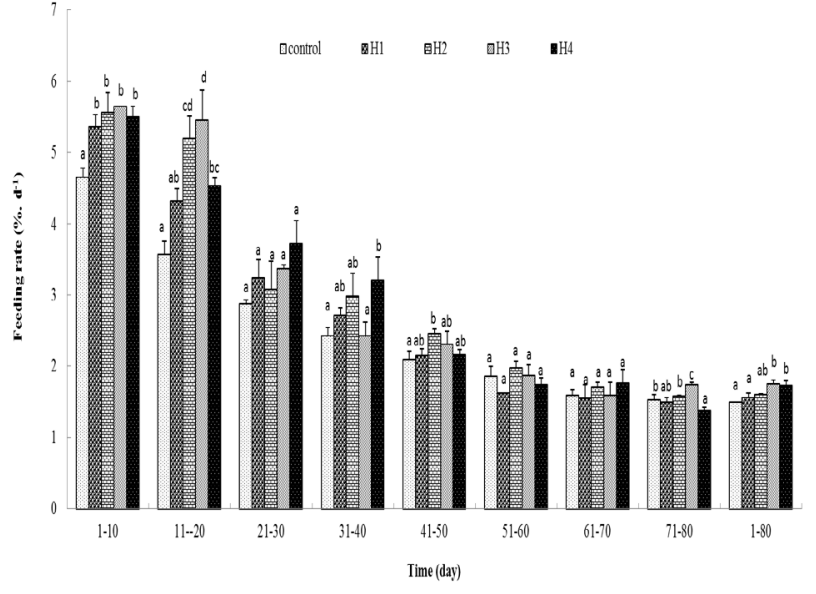

Figure 3: Feeding rate (\% body weight. $\left.\mathrm{d}^{-1}\right)$ of the juvenile P.olivaceus. Column without same letter in the same cluster were significantly different from each other $(\mathrm{P}<0.05)$.

\section{Discussion}

For most fishes, growth rate is positively related to temperature as it is below the optimal temperature for growth, but the growth rate of fish would decrease (still higher than the growth rate at lowtemperature) as temperature exceeded the upper limitation of suitable scope ${ }^{[12-19]}$. In general, fish reared at high temperature would consume large amount of food no less thanfish reared at optimal temperature for growth ${ }^{[13,14,19]}$. But large food consumption at high temperature may not result in fast growth. Fish consume more food at high temperature could attributed to fast stomach evacuation ${ }^{[14]}$. But as they allocated more energy in metabolism of maintenance demand ${ }^{[17,20-22]}$, less energy could be used to growth andpoor feed conversion efficiency(FCE) or feed conversion ratio (FCR)appeared ${ }^{[14,16,19,22]}$. Thus, fish reared at high temperature growth slower than those reared at optimal temperature. Juvenile brown flouder reared at $26.5^{\circ} \mathrm{C}$ for 10 days consumed slightly lessfoodthan those reared at $22.0^{\circ} \mathrm{C}^{[6,23]}$. In the present study, feeding rate of fish exposed to high temperature was significantly higher than the control as they were challenged by high temperature for 20,30, and 40 days (table 3 ). But similar to previous study, Juvenile brown flounder reared at $26.5^{\circ} \mathrm{C}$ did not grow faster than fish reared at optimal temperature $\left(22.0^{\circ} \mathrm{C}\right)$. As revealed by the previous energetics study on brown flounder, fish consumed more oxygen and excreted more ammonia at high ${ }^{[20,21]}$ and it meant more energy demand for metabolism maintenance ${ }^{[12]}$ believed that more energy expenditure on metabolism and excretion in juvenile brown flounder reared at high temperature leaded to less energy deposition. And it accounted for poor growth and feed conversion efficiency of high temperature stress period in the present study and previous study conducted by ${ }^{[6]}$. Compensatory growth of fish is considered as an important ecological strategy to adaptive fluctuant environments ${ }^{[18,25,33]}$. Several species demonstratedhigh capacity of low temperature adaptivity by compensating the growth depression caused by low temperature ${ }^{[1,2,4-8]}$. High temperature stress induced compensatory growth was rarelyreported. Consistent withthe findings of $^{[6]}$, juvenile brown flouder achieved completely compensatory growth following being reared at $26.5^{\circ} \mathrm{C}$ for 10 days and 20 days. But no compensatory growth appeared in 30 and 40 days high temperature exposuregroup.It suggested thatjuvenile could be reared at $26.5^{\circ} \mathrm{C}$ for no longer than 20 days and it would not produce negative effects on the growthin a long period.In another benthic fish, tongue sole (Cynoglossussemilaevis), complete compensatory growth appeared in juvenile fish reared at $28^{\circ} \mathrm{C}$ for 2 and 3 weeks $s^{[9]}$. It could be concluded that of brown flounder and tongue sole possess similar adaptivity to high temperature. Brown flounder and tongue sole are important species for mariculture and enhancement in coastal China. The culture and enhancement of these two species were developed firstly in northern coastal region of China and spreaded to southern coastal region of China in the recent years. High temperature would occur more frequently and last for longer time in southern coastal region of China. The results of the present study and ${ }^{[9]}$ exhibited high capacity of high temperature adaptively of brown flounder and tongue sole. Overall, these findings may have important consequences for optimization of culture and enhancement of brown flounder and tongue sole.

Compensatory growth was defined as a phase of accelerated growth when favorable conditions are restored after a period of growth depression ${ }^{[24]}$, so higher growth rate of fish was the main feature of this stage. The time length of this phase differs among fish species and studies ${ }^{[1,2,6,8,9,26,27]}$. In the present study, juvenile fish reared at high temperature for 10 days need only 10 days to achieved completely compensatory growth and juvenile fish reared at high temperature for 20 days need more than 30 days (Figure 1). As mentioned by ${ }^{[28]}$, for those fish achieved partially compensatory growth, specific growth rate (SGR) could not be used as a direct parameter to discriminate compensatory growth and should be adjusted (several methods provided in their review). It was also difficult to point out in "which 10 days" the compensatory growth occurred in fish received 20 days high temperature exposure because no phase with significant higher specific growth rate (SGR) appeared (Figure 2 ), though completely compensatory growth appeared (Figure 1). So, it could be supposed that the compensatory growth of juvenile brown flounder in this treatment was not burst in a short period, but continuous and cumulative.

So far, the mechanisms for compensatory growth of P.olivaceushave been mostly explained as individual, mostly by analyzing the dynamics of feeding, feed conversion efficiency and energy use in stress and recovery period. Compensatory growth is partly a response to hyperphagia ${ }^{[9,2]}$ and improved FCE ${ }^{[30,31]}$. Compensatory growth in P.olivaceusexperienced low temperatures could be attributed to improvement in the feeding rate ${ }^{[6,12,7]}$. Similar results have also been reported in other fish species $^{[20]}$. However, improved feed conversion efficiencies have been observed in other studies ${ }^{[5,9,12]}$ found that higher feed efficiency and apparent digestion rate during recovery period might account for the compensatory growth in tongue sole following high temperature exposure. In the present study, juvenile brown flounder reared at $26.5^{\circ} \mathrm{C}$ for 10 days and 20 day achieved completely compensatory growth. Superficially, in high temperature exposed juvenile brown flounder, only short-term significant higher feeding rate appeared in recovery periods and the feed conversion did never exceed the control. This may lead to a false conclusion that the compensatory growth of the present study achieved mainly by higher feeding rate, hyperphagia. Careful analysis of the data in table 3-6 indicated that in the recovery 
periods, the feed conversion efficiency (FCE) of high temperature exposed fish improved greatly.Though FCE were not better than the control, but the gap, which were larger than $40 \%$ in high temperature stressing period, narrowed to not obviously in treatments and achieved completely compensatory growth. On the contrary, though the feeding rate of these two treatments in recovery periods did not fall below the control, the gap between high temperature exposed fish and the control reduced to not obviously. It means that no continuous hyper phage appeared in recovery periods. So, it could be concluded that the compensatory growth of the present study should mainly be attributed to greatly improvement on feed conversion efficiency and slightly higher feeding rate played a less important pole. Results in the present study on brown flounder and ${ }^{[9]}$ study on tongue sole indicated that though hyperphagia played an important role in compensatory growth for feed-restricted fish, it may not be a major pole in the compensatory response in high temperature stressed fish.

\section{Conclusion}

In conclusion, this study presents the length of high temperature exposure and growth of juvenile brown flounder (Paralichthysolivaceus) and the underlying compensatory mechanisms. The high temperature stress period should not exceed 20 days. Once high-temperature exposure reached 30 days, the fish could not gain complete compensatory growth in 50 days. The slow growth of juvenile brown flounder exposed to high temperature was caused primarily by low FCE, the compensatory growth in the recovery period depended on greatly improved feed conversion efficiency and slightly higher feeding rate.

Acknowledgement: The study was supported by the National Natural Science Foundation of China (No. 30600462).

\section{References}

1. Mortensen, A., Damsgård, B. Compensatory growth and weight segregation following light and temperature manipulation of juvenile Atlantic salmon (Salmo salar L.) and Arctic charr (SalvelinusalpinusL.). (1993) Aquaculture 114(3-4): 261272.

Pubmed $\mid$ Crossref $\mid$ Others

2. Nicieza, A.G., Metcalfe, N.B. Effects of light levels and growth history on attack distances of visually foraging juvenile Atlantic salmon in experimental tanks. (1997) Journal of Fish Biology 51(3): 643-649.

Pubmed | Crossref $\mid$ Others

3. Chmilevskii, D.The influence of low temperature on the growth of Oreochromis mossambicus. (1998) Journal of Ichthyology 38(1): 92-99.

Pubmed $\mid$ Crossref $\mid$ Others

4. Purchase, C.F., Brown, J.A. Stock-specific changes in growth rates, food conversion efficiencies, and energy allocation in response to temperature change in juvenile Atlantic cod. (2001) Journal of Fish Biology 58(1): 36-52.

Pubmed $\mid$ Crossref $\mid$ Others

5. Wang, X.J., Zhang, X M., Huang, G.Q. Compensatory growth of rockfish (Sebastes schlegeli) following low temperature stress. (2006) Journal of Fishery Sciences of China 13(4):566572.

Pubmed | Crossref | Others

6. Huang, G.Q., Wei, L.Z., Zhang, X.M., et al. Compensatory growth of juvenile brown flounder Paralichthysolivaceus (Temminck\& Schlegel) following thermal manipulation. (2008) Journal of Fish Biology 72(10): 2534-2542.

Pubmed | Crossref $\mid$ Others

7. Peng, Y.H., Liu, X.J., Huang, G.Q., et al. Compensatory growth of juvenile brown flounder Paralichthysolivaceus following low temperature challenge of different durations. (2017) Journal of Ocean University of China.

Pubmed | Crossref $\mid$ Others

8. Fang, J.H., Tian,X.L., Dong, S.L. The influence of water temperature and ratio on the growth, body composition and energy budget of tongue sole, Cynoglossussemilaevis. (2010) Aquaculture 299(1-4):106-114.

Pubmed | Crossref $\mid$ Others

9. Fang, J.H., Tian, X.L.,Dong, S.L., et al. Growth compensation in juvenile tongue sole, Cynoglossussemilaevis (Güther, 1873):responses to thermal stress and feed restriction. (2014) Aquaculture Research 46(11):2604-2614.

Pubmed | Crossref $\mid$ Others

10. Lou, B., Xu, D.D., Xu, H.X., et al. Effect of high water temperature on growth, survival and antioxidant enzyme activities in the Japanese flounder Paralichthysolivaceus. (2011) African Journal of Agricultural Research6(12): 2875-2882.

Pubmed | Crossref $\mid$ Others

11. Iwata, N., Kikuchi, K., Kurokura, H. Growth of Japanese flounder Paralichthysolivaceus at different temperatures. (1995) Israeli Journal of Aquaculture-Bamidgeh 47(3): 178-184.

Pubmed | Crossref $\mid$ Others

12. Marine, K.R., Cech Jr, J.J. Effects of high water temperature on growth, smoltification, and predator avoidance in Juvenile Sacramento River Chinook salmon. (2004) North American Journal of Fisheries Management24(1): 198-210.

Pubmed | Crossref | Others

13. Person-Le, R.J., Mahe, K., Le Bayon, N., et al. Effects of temperature on somatic growth and metabolism in a Mediterranean population of European sea bass, Dicentrarchuslabrax. (2004) Aquaculture 237(1-4): 269-280.

Pubmed | Crossref | Others

14. Handeland, S.O., Imsland, A.K.,Stefansson, S.O. The effect of temperature and fish size on growth, feed intake, food conversion efficiency and stomach evacuation rate of Atlantic Salmon post-smolts. (2008) Aquaculture 283(1-4): 36-42.

Pubmed | Crossref | Others

15. Munday, P.L., Kingsford, M.J.,O’Callaghan, M. Elevated temperature restricts growth potential of the coral reef fish $\mathrm{Ac}$ anthochromispolyacanthus. (2008) Coral Reefs27(4): 927-931. Pubmed | Crossref $\mid$ Others

16. Árnason, T., Björnsson, B.T., Steinarsson, A., et al. Effects of temperature and body weight on growth rate and feed conversion ratio in turbot (Scophthalmus maximus). (2009) Aquaculture 295(3-4): 218-225.

Pubmed | Crossref | Others

17. Neuheimer, A.B., Thresher, R.E., Lyle, J.M., et al. Tolerance limit for fish growth exceeded by warming waters. (2011) Na- 
ture Climate Change1(2): 110-113.

Pubmed |Crossref $\mid$ Others

18. Booth, D.J., Poulos, D.E., Poole, J., et al. Growth and temperature relationships for juvenile fish species in seagrass beds: implications of climate change. (2014) Journal of Fish Biology 84(1): 231-236.

Pubmed | Crossref $\mid$ Others

19. Sun, L.H., Chen, H. R. Effects of water temperature and fish size on growth and bioenergetics of cobia (Rachycentroncanadum).(2014) Aquaculture426-427(2): 172-180.

Pubmed | Crossref | Others

20. Zhang, Z.Q., Zhang, M.Z., Li, J.Q., et al. Oxygen consumption and nitrogen excretion of Paralichthysolivaceus with different body weights at different water temperature. (1997) Journal of Ocean University of Qingdao 27(4): 483-489.

Pubmed | Crossref | Others

21. Zhang, M.Z., Zhang, Z.Q., Zheng, C.B., et al. Energy metabolism of juvenile Japanese flounder, Paralichthysolivaceus. (1999)Journal of Fishery Sciences of China 6(1): 75-78.

Pubmed | Crossref | Others

22. Glencross, B., Bermudes, M. Effect of high water temperatures on the utilisation efficiencies of energy and protein by juvenile Barramundi, Latescalcarifer.(2010) Fisheries and Aquaculture Journal 14:1-11.

Pubmed | Crossref $\mid$ Others

23. Huang, G.Q., Wei, L.Z., Zhang, X.M., et al. The growth and energy allocation of the brown flounder, Paralichthysolivaceus during thermal Manipulation. (2010) Periodical of Ocean University of China 40(2): 38-46.

Pubmed | Crossref $\mid$ Others

24. Ali, M., Nicieza, A., Wootton, R.J. Compensatory growth in fishes: a response to growth depression. (2003) Fish \& Fisheries 4(2):147-190.

Pubmed $\mid$ Crossref $\mid$ Others

25. Näslund, J., Sundström, L.F., Johnsson, J.I. Autumn food restriction reduces smoltification rate, but not over-winter survival, in juvenile brown trout Salmo trutta. (2015) Ecology of Freshwater Fish 26(2): 205-216.

Pubmed | Crossref $\mid$ Others

26. Wang, Q.K., Jiang, Z.Q., Wang, J.B., et al. The effects of starvation on refeeding and growth in Japanese flounder Paralichthysolivaceus.(2011) Journal of Dalian Ocean University 26(1): 47-53

Pubmed | Crossref | Others

27. Yengkokpam, S., Sahu, N.P., Pal, A.K., et al. Compensatory growth, feed intake and body composition of Labeorohita fingerlings following feed deprivation. (2014) Aquaculture Nutrition 20(2): 101-108.

Pubmed $\mid$ Crossref $\mid$ Others

28. Wang, Y., Cui, Z.H. Some problems in studies on compensatory growth in fish. (2003) Journal of Shanghai Fisheries University, 12(3): 260-264.

Pubmed | Crossref $\mid$ Others

29. Hayward, R.S., Noltie, D.B., Wang, N. Use of compensatory growth to double hybrid sunfish growth rates. (1997) Transactions of the American Fisheries Society 126(2): 316-322.

Pubmed | Crossref $\mid$ Others

30. Russell, N.R., Wootton, R.J. Appetite and growth compensation in European minnows, Phoxinusphoxinus (Cyprinidae), fol- lowing short periods of food restriction. (1992) Environmental Biology of Fishes 34(3): 277-285.

Pubmed | Crossref $\mid$ Others

31. Wu, L.X., Dong, S.L., Wang, F., et al. Compensatory growth response following periods of starvation in Chinese shrimp, Fenneropenaeuschinensis Osbeck. (2000) Journal of Shellfish Research 19(2): 717-722.

Pubmed | Crossref $\mid$ Others

32. Wu, Y.B., Wu, L.X., Chen, J., et al. Influence of starvation on juvenile Paralichthysolivaceus compensatory growth, biochemical composition, and energy budget. (2011) Chinese Journal of Ecology 30(8): 1691-1695.

Pubmed | Crossref $\mid$ Others

33. John, A.N. Growth and energy metabolism in Atlantic salmon (Salmo salar), with possible positive effects of starvation at elevated temperature. (2014) The University of Bergen and National.

Pubmed $\mid$ Crossref $\mid$ Others

Submit your manuscript to Ommega Publishers and we will help you at every step:

- We accept pre-submission inquiries

- Our selector tool helps you to find the most relevant journal

- We provide round the clock customer support

- Convenient online submission

- Thorough peer review

- Inclusion in all major indexing services

- Maximum visibility for your research

Submit your manuscript at

OMMEgA Publishers

https://www.ommegaonline.org/submit-manuscript 